\title{
Correction to: Open research data, an archival challenge?
}

\author{
Charlotte Borgerud ${ }^{1}\left[\right.$ (C) Erik Borglund ${ }^{2}$ (1)
}

Published online: 19 March 2020

(c) The Author(s) 2020

\section{Correction to: Archival Science https://doi.org/10.1007/s10502-020-09330-3}

In the original publication of the article, the third sentence in the third paragraph under the section "Methods" was incorrect. The correct sentence should read as given below:

"Ten respondents represent the universities, and five the various public authorities."

The original article has been updated accordingly.

Open Access This article is licensed under a Creative Commons Attribution 4.0 International License, which permits use, sharing, adaptation, distribution and reproduction in any medium or format, as long as you give appropriate credit to the original author(s) and the source, provide a link to the Creative Commons licence, and indicate if changes were made. The images or other third party material in this article are included in the article's Creative Commons licence, unless indicated otherwise in a credit line to the material. If material is not included in the article's Creative Commons licence and your intended use is not permitted by statutory regulation or exceeds the permitted use, you will need to obtain permission directly from the copyright holder. To view a copy of this licence, visit http://creativecommons.org/licen ses/by/4.0/.

Publisher's Note Springer Nature remains neutral with regard to jurisdictional claims in published maps and institutional affiliations.

The original article can be found online at https://doi.org/10.1007/s10502-020-09330-3.

Erik Borglund

erik.borglund@miun.se

Charlotte Borgerud

charlotte.borgerud@skr.se

1 Swedish Association of Local Authorities and Regions, 11882 Stockholm, Sweden

2 Mid Sweden University, 85170 Sundsvall, Sweden 